\title{
Why Is Open Regionalism Not Always Good?
}

\author{
Wai-Heng Loke \\ University of Nottingham Ningbo China \\ L. Alan Winters \\ University of Sussex
}

\begin{abstract}
When the Asia Pacific Economic Cooperation (APEC) formally adopted the principle of "open regionalism" (OR) in its trade liberalization in 1991, many were optimistic that this approach suggested the bloc as a stepping stone toward global free trade. This optimistic view was reinforced by the economic theorizing of Sang-Seung Yi (1996). This paper shows formally via a simple model why OR may fail. We unpick Yi (1996) systematically and explain that OR works in his model because of quasilinear preferences and Ricardian technology assumptions. Once these assumptions are replaced with constant elasticity of substitution (CES) preferences and increasing marginal costs, OR fails to ensure global free trade as an equilibrium when the world consists of a country that is sufficiently larger than the rest of the world.
\end{abstract}

JEL Classifications: F12, F13, F15

Key Words: Regional Integration, Equilibrium Coalition Structure, Welfare

\footnotetext{
* Corresponding Author: Wai-Heng Loke; Division of Economics, University of Nottingham Ningbo China, 199 Taikang East Road, Ningbo, 315100, China, Tel: +86 (0)574 8818 2637, Fax: +603 7967 3719, Email: waiheng.loke@nottingham.edu.cu; Co-Authour: L. Alan Winters; Department of Economic, University of Sussex, Brighton, BN1 9SL, Great Britain, Tel: +44 (0) 1273 678332, Fax: +44 1273 873715, Email: L.A.Winters@sussex.ac.uk.
} 


\section{Introduction}

Policy-makers still frequently ask: Are regional trading blocs stepping stones or stumbling blocks toward global free trade? Is it possible to design a rule for trading bloc formation that will sustain global free trade as a stable equilibrium coalition structure?

Prior to the 1997-98 Asian financial crisis, "open regionalism" was held to offer an affirmative answer. The Asia Pacific Economic Cooperation (APEC) adopted it as the key principle of trade liberalization in 1991 and supporters (Bergstern in 1997, for example) viewed $\mathrm{OR}$ as a recipe for building non-discriminatory regional trading blocs and hence believed that regional liberalization could be achieved without undermining eff orts at the multilateral level. Their optimistic view was greatly reinforced by the economic theorizing of Yi (1996a).

Yi (1996) addressed these questions in a model with closed form solutions and produced neat analytical results which concluded that if we adopted "open regionalism" as a rule for trade bloc formation, global free trade could be a stable equilibrium outcome.

Bhagwati (2006) and Garnaut (2004) argued that APEC should continue to embrace it in its pursuit of trade liberalization. Given the current spaghetti-bowl that results from having many overlapping free trade agreements (FTAs), some experts have suggested a modified version of OR. For example, Garnaut and Vines (2007) proposed open trading arrangements (OTA), which contained the key element of the original concept of OR-open membership. The precise details of the OTA were not clear, but Garnaut (2004) suggested that OTAs were best initiated among "economies of substantial size" and that once one was established by two or more economies, it may become attractive to new members in the Asia Pacific region and beyond.

The model in this paper suggests that a key challenge to the success of OTA is to generate sufficient interest among "economies of substantial size" to take the first step of initiation since they may well not wish to get seriously involved in a trading arrangement with open membership as a rule. This paper shows formally why OR may fail, based on theory and simple simulation modeling. We unpick Yi (1996) systematically and show that open regionalism works in his model only because of quasilinear preferences and Ricardian technology assumptions. Once these assumptions are replaced (e.g., with CES preferences and a concave production possibility curve), OR may fail to ensure global free trade as an equilibrium in a world of different-sized countries even if the rest of the world adopts an open regionalism rule as a strategy.

Google Scholar records that Yi (1996a) has been cited 190 times (as on Dec. 16, 2010). Two recent examples are Chen \& Joshi (2010) and Seidmann (2009). 
The remainder of the paper is organized as follows: A detailed review of Yi's model (1996a) in Section 2. A demonstration of how Yi's claims about open regionalism rule collapse when his assumptions of quasilinear preferences and Ricardian technology are replaced with CES utility function and a non-Ricardian technology in Section 3. An examination of the effects of varying the slope of marginal cost on the modified model and on the size of a larger country that would block progress towards free trade in Section 4. A conclusion in Section 5.

\section{Open Regionalism is Good: Yi's Model}

Yi (1996a) considers rules for enlarging a customs union. He provides a formal analysis of two different membership rules - open regionalism and unanimous regionalism — on the equilibrium structure of customs union. ${ }^{2}$ Open regionalism is interpreted as a rule where a nonmember country can join a customs union without having to obtain the consent of the existing members of the union. In other words, open regionalism is defined as open membership. Under the unanimous regionalism rule on the other hand, a nonmember country can join a customs union only when all existing members agree.

An open regionalism rule prevents existing member countries from rejecting outsiders for fear of possibly compromising their welfare. Yi finds that this leads customs unions to expand until they include all countries in the world - the grand coalition - and thus he claims that it renders customs unions stepping stones to global trade liberalization.

Yi's model assumes a world with $\mathrm{N}$ countries symmetric in all aspects. Each country is endowed with some amount of a numeraire good that can be transformed into a non-numeraire good at a constant marginal cost. The non-numeraire goods are differentiated between countries, with each country producing precisely one. There is only one firm in each country producing the non-numeraire good. Firms are assumed to be in Cournot competition and consumers are assumed to have quasilinear preferences. The numeraire good is traded freely across countries while trade in the differentiated good is subject to tariffs.

\section{A. Quasilinear Preferences}

\section{Demand is Independent of Income}

Yi assumes that the utility function of a representative consumer in country $i$ has the form of

\footnotetext{
${ }^{2}$ In another paper, Yi has used a simple four-country example to illustrate his model in comparing the effects of the two membership rules on the equilibrium customs union structure (Yi, 1996b).
} 


$$
\mathrm{u}^{\mathrm{i}}\left(q_{i} ; \mathrm{M}\right)=\mathrm{v}\left(q_{i}\right)+\mathrm{M}_{\mathrm{i}}=a \mathrm{Q}_{\mathrm{i}}-\frac{\gamma}{2} Q_{i}^{2}-\frac{1-\gamma}{2} \sum_{j=1}^{N} q_{i j}^{2}+M_{i}
$$

where $q_{i j}$ is country $i$ 's consumption of country $j$ 's product, $q_{i} \equiv\left(q_{i 1}, q_{i 2}, \ldots, q_{i N}\right)$ is country i's consumption profile, $\mathrm{Q}_{\mathrm{i}} \equiv \sum_{j=1}^{N} q_{i j}$, g is a substitution index between goods, and $M_{i}$ is country $i$ 's consumption of the numeraire good. The numeraire good will be transferred across countries to settle, if there is any, the balance of trade. The model further assumes that each country's endowment of the numeraire good is sufficient to guarantee a positive consumption of the numeraire good in each country.

$$
M_{i}=Y^{i}-\sum_{j=1}^{N} p_{i j}^{*} q_{i j}
$$

Note that the maximization problem is reduced to an unconstrained maximization problem (Varian, 1992):

$$
\max \quad \mathrm{u}^{\mathrm{i}}=a \mathrm{Q}_{\mathrm{i}}-\frac{\gamma}{2} Q_{i}^{2}-\frac{1-\gamma}{2} \sum_{j=1}^{N} q_{i j}^{2}+\mathrm{Y}^{\mathrm{i}}-\sum_{j=1}^{N} p_{i j}^{*} q_{i j}
$$

where $\mathrm{Y}^{\mathrm{i}}$ is the income of country $i$.

The first order condition for good $q_{i l}$, for example, is

$$
\partial \mathrm{u}^{\mathrm{i}} / \partial q_{i 1}=a-(1-\gamma) q_{i 1}-\gamma Q-p_{i 1}=0
$$

The inverse demand function for good $q_{i l}$ is therefore

$$
p_{i 1}=a-(1-\gamma) q_{i 1}-\gamma Q_{i}
$$

The demand function above shows that demand for $q_{i 1}$ depends on $p_{i 1}$ which is its own price in country $\mathrm{i}$, and $Q_{i}$ which is $\sum_{j=1}^{N} q_{i j}$. It is also independent of income Y. Hence there is zero income effect on good $q_{i l}$ and also all other non-numeraire goods. Any increase in income will be used to consume the numeraire good $M$.

A zero income effect on the non-numeraire good also means that changes in tariffs will not have income effects on the consumption of the non-numeraire goods. This zero income effect is useful for Yi to solve his model analytically as it means that optimal tariffs are independent across countries (this is shown in the following subsection) and hence the optimal tariffs of a customs union are dependent only on the size of the customs union relative to the rest of the world and not on the coalition structures in the world. ${ }^{3}$

\footnotetext{
${ }^{3}$ We show later in the paper that this quasilinear utility assumption is necessary but not sufficient to produce independent optimal tariffs among customs unions. The assumption of constant marginal cost in Yi's model is also crucial in order to arrive at this result.
} 


\section{No Strategic Interdependence of Optimal Tariffs Across Countries/Customs Unions}

Yi assumes no transportation costs and non-negative specific tariffs $\left(\tau_{i j}\right)$. The effective marginal cost of the good from country $j$ in country $i$ is therefore

$$
c_{i j}=c+\tau_{i j}
$$

where $c_{i j}$ : effective marginal cost

$$
\begin{aligned}
& c: \text { marginal cost (assumed common to all producers) } \\
& \tau_{i j}: \text { tariff }
\end{aligned}
$$

The model further assumes that markets are segmented and that firms compete by choosing quantities in each country. Markets between countries are completely separated, which, given the assumption of constant marginal cost, means that changes in demand for a differentiated good in one country have no effect on marginal costs of production anywhere. In country $i$, country $j$ 's firm will solve

$$
\operatorname{Max}_{\left\{q_{i j}\right\}} \pi^{i j}=\left(p_{i j}-c_{i j}\right) q_{i j}
$$

The first order condition for profit maximization is therefore

$$
p_{i j}-c_{i j}-q_{i j}=0
$$

which can be rewritten using Equations 2 and 3 as

$$
\alpha-\tau_{i j}-(2-g) q_{i j}-\gamma Q_{i}=0
$$

where $\alpha \equiv a-\mathrm{c}$. Normalizing $\alpha=1$ and summing the first order conditions over $j, j=1,2, . .$, $\mathrm{N}$, in the Cournot equilibrium ${ }^{4}$

$$
Q_{i}=\frac{N-T_{i}}{\Gamma(N)}, \text { and } q_{i j}=\frac{\Gamma(0)+\gamma T_{i}-\Gamma(N) \tau_{i j}}{\Gamma(0) \Gamma(N)}
$$

where $\mathrm{T}_{\mathrm{i}} \equiv \sum_{j=1}^{N} \tau_{i j}$ is the sum of tariffs and

$$
\Gamma(k) \equiv 2-\gamma+k \gamma, k=1,2, \ldots, N
$$

Equations 4 and 5 show that the equilibrium $q_{i j}$ depends only on country $i$ 's tariffs; i.e.,

\footnotetext{
${ }^{4}$ The value of a actually has an effect on the value of equilibrium quantities and optimal tariffs but it does not affect the signs of these variables. Normalizing $\alpha=1$ makes Equation 5 neat without changing the signs of these variables in subsequent Equations 7 and 8 and hence does not change the qualitative results.
} 
product market equilibrium in country $i$ depends only on country i's tariffs. A change in country $i$ 's tariffs on imports from country $j$ does not affect product market equilibria in any other countries. The effects of the tariff on country $j$ occur solely on the numeraire good as transfers of numeraire good from country $j$ to country $i$ settle the balance of trade. As a result, the optimal tariff of a country / customs union does not depend on the tariffs of the rest of the world. This implies that there is no strategic interdependence of optimal tariffs across countries/ customs unions.

To illustrate in a two-country model, Equation 4 becomes

$$
\begin{array}{lll}
\alpha-\tau_{12}-(2-\gamma) q_{12}-\gamma Q_{1}=0 & \text { (4a) where } Q_{1}=q_{11}+q_{12} \text { for country } 1 \text { and } \\
\alpha-\tau_{21}-(2-\gamma) q_{21}-\gamma Q_{2}=0 & \text { (4b) where } Q_{2}=q_{22}+q_{21} \text { for country } 2
\end{array}
$$

Say there is an increase in tariff $\tau_{21}$ by country 1 on $q_{12}$; i.e., imports from country 2 . From Equation $4 \mathrm{a}$, we can see that this will reduce the amount of $q_{12}$. But the increase of $\tau_{21}$ does not affect the consumption of $q_{2 l}$; i.e., country 2 's import of the non-numeraire good from country 1 even though country 2 's exports to country 1 is reduced due to the rise in $\tau_{21}$. This is evident from Equation $4 \mathrm{~b}$ which shows that the equilibrium amount of $q_{21}$ is independent of the equilibrium amount of $q_{12}$.

\section{Effects of Tariff on the Consumption of Home and Imported Goods and} on Home and Foreign Firms' Profits

From Equation 5,

$$
\begin{aligned}
& \frac{d Q_{i}}{d \tau_{i j}}=-\frac{1}{\Gamma(N)}<0 \\
& \frac{d q_{i k}}{d \tau_{i j}}=\frac{\gamma}{\Gamma(0) \Gamma(N)}>0, \text { for } k^{1} j, \text { and } \frac{d q_{i j}}{d \tau_{i j}}=\frac{\gamma-\Gamma(N)}{\Gamma(0) \Gamma(N)}<0
\end{aligned}
$$

Equations 7 and 8 show that if country $i$ raises its tariffs on imports from country $j$, then consumption of good $j$ and total consumption in country $i$ falls, and consumption of all other goods increases. Country $j$ 's Cournot equilibrium export profit to country $i$ is given by

$$
\pi_{i j}=\left(p_{i j}-c_{i j}\right) q_{i j}=q_{i j}^{2}
$$

using the first order condition. Hence,

$$
\frac{d \pi^{i k}}{d \tau_{i j}}=2 q_{i k} \quad \frac{d q_{i k}}{d \tau_{i j}}=\frac{2 \gamma q_{i k}}{\Gamma(0) \Gamma(N)}>0, \quad \text { for } k \neq j,
$$




$$
\frac{d \pi^{i j}}{d \tau_{i j}}=\frac{2[\gamma-\Gamma(N)] q_{i k}}{\Gamma(0) \Gamma(N)}<0
$$

Equations 10 and 11 show that when country $i$ raises tariffs on imports from country $j$, then country $j$ 's export profit to country $i$ falls, and country $i$ 's home firm profit and all other countries' export profits to country $i$ rise. Hence, when country $i$ raises its tariffs on imports from country $j$, country $j$ 's terms of trade with country $i$ deteriorate and all other countries' terms of trade with country $i$ improve.

\section{B. Constant Marginal Cost}

The second critical assumption concerns the production technology. Yi assumes each country is endowed with equal amounts of numeraire good which can be transformed into a non-numeraire good at constant marginal cost. This is essentially a model with Ricardian technology where the production possibility frontier of a country is a downward sloping straight line. With Ricardian technology where all countries face horizontal marginal cost curves, the terms of trade are fixed between countries - hence the rationale for an optimal tariff based on the ability of the home country to influence its terms of trade disappears.

\section{Replicating Yi's Model with Numerical Simulations}

This section provides numerical simulations that replicate Yi's results. Setting up Yi's framework in a numerical model provides the basis for modifications in subsequent sections.

From Equation 1, we set the model's parameter values as follows:

$$
a=2 ; c=1 ; \gamma=0.5 ; E=10
$$

where $a$ : utility function parameter

$c$ : marginal cost

$\gamma$ : substitution index; a value of 0.5 indicates imperfect substitution between goods

$E$ : endowment of numeraire good in each country

We conduct two simulations: (i) A world model with only 2 symmetric countries; country 1 being the active country, setting an optimal tariff, while country 2 is passive meaning its tariff on imports is zero. (ii) A world with 5 countries where all countries are active with tariff as a policy tool. 
The results are shown in Tables 1 and 2.

Table 1. Optimal Tariff of Country 1 when Country 2 is Passive

\begin{tabular}{|l|l|l|l|l|l|l|l|l|}
\hline $\begin{array}{c}\text { Trade } \\
\text { Scenario }\end{array}$ & Country & Welfare & $\begin{array}{c}\text { Tariff } \\
\text { on } \\
\text { Good 1 }\end{array}$ & $\begin{array}{c}\text { Tariff } \\
\text { on } \\
\text { Good 2 }\end{array}$ & $\begin{array}{c}\text { Price } \\
\text { of } \\
\text { Good 1 }\end{array}$ & $\begin{array}{c}\text { Price } \\
\text { of } \\
\text { Good 2 }\end{array}$ & $\begin{array}{c}\text { Consumption } \\
\text { of } \\
\text { Good 1 }\end{array}$ & $\begin{array}{c}\text { Consumption } \\
\text { of } \\
\text { Good 2 }\end{array}$ \\
\hline Free Trade & 1 & 10.560 & 0 & 0 & 1.400 & 1.400 & 0.400 & 0.400 \\
\hline & 2 & 10.560 & 0 & 0 & 1.400 & 1.400 & 0.400 & 0.400 \\
\hline $\begin{array}{l}\text { Country 1 } \\
\text { sets optimal } \\
\text { tariff only }\end{array}$ & 1 & 10.604 & 0 & 0.333 & 1.444 & 1.556 & 0.444 & 0.222 \\
\hline & 2 & 10.449 & 0 & 0 & 1.400 & 1.400 & 0.400 & 0.400 \\
\hline
\end{tabular}

Rows 1 and 2 of Table 1 report the free trade benchmark. Rows 3 and 4 show that when country 1 sets a tariff on imports from country 2, country 2's consumption of goods 1 and 2 remains unchanged. With constant marginal cost, optimal tariffs are also independent across countries in the multi-country case. As shown in Table 2, the optimal tariff of a country/ customs union depends only on its size relative to the world, and in particular not the tariffs of other countries.

Table 2. A World with 5 Symmetric Countries: All Countries are Active

\begin{tabular}{|l|c|c|c|c|c|c|c|}
\hline \multirow{2}{*}{ Trade Scenario } & \multirow{2}{*}{ Country } & \multirow{2}{*}{ Utility } & \multicolumn{6}{|c|}{ Tariff on Good } \\
& & & 1 & 2 & 3 & 4 & 5 \\
\hline No CU & 1 & 10.6944 & 0 & 0.2500 & 0.2500 & 0.2500 & 0.2500 \\
\hline & 2 & 10.6944 & 0.2500 & 0 & 0.2500 & 0.2500 & 0.2500 \\
\hline & 3 & 10.6944 & 0.2500 & 0.2500 & 0 & 0.2500 & 0.2500 \\
\hline & 4 & 10.6944 & 0.2500 & 0.2500 & 0.2500 & 0 & 0.2500 \\
\hline & 5 & 10.6944 & 0.2500 & 0.2500 & 0.2500 & 0.2500 & 0 \\
\hline CU (1,2) & 1 & 10.735 & 0 & 0 & 0.2658 & 0.2658 & 0.2658 \\
\hline & 2 & 10.735 & 0 & 0 & 0.2658 & 0.2658 & 0.2658 \\
\hline & 3 & 10.678 & 0.2500 & 0.2500 & 0 & 0.2500 & 0.2500 \\
\hline & 4 & 10.678 & 0.2500 & 0.2500 & 0.2500 & 0 & 0.2500 \\
\hline & 5 & 10.678 & 0.2500 & 0.2500 & 0.2500 & 0.2500 & 0 \\
\hline CU $(1,2,3)$ & 1 & 10.761 & 0 & 0 & 0 & 0.2647 & 0.2647 \\
\hline & 2 & 10.761 & 0 & 0 & 0 & 0.2647 & 0.2647 \\
\hline & 3 & 10.761 & 0 & 0 & 0 & 0.2647 & 0.2647 \\
\hline & 4 & 10.653 & 0.2500 & 0.2500 & 0.2500 & 0 & 0.2500 \\
\hline & 5 & 10.653 & 0.2500 & 0.2500 & 0.2500 & 0.2500 & 0 \\
\hline
\end{tabular}




\begin{tabular}{|l|c|c|c|c|c|c|c|}
\hline \multirow{2}{*}{ Trade Scenario } & \multirow{2}{*}{ Country } & Utility & \multicolumn{6}{|c|}{ Tariff on Good } \\
& & & 1 & 2 & 3 & 4 & 5 \\
\hline CU $(1,2,3,4)$ & 1 & 10.776 & 0 & 0 & 0 & 0 & 0.256 \\
\hline & 2 & 10.776 & 0 & 0 & 0 & 0 & 0.256 \\
\hline & 3 & 10.776 & 0 & 0 & 0 & 0 & 0.256 \\
\hline & 4 & 10.776 & 0 & 0 & 0 & 0 & 0.256 \\
\hline & 5 & 10.624 & 0.2500 & 0.2500 & 0.2500 & 0.2500 & 0 \\
\hline Grand Customs & 1 & 10.781 & 0 & 0 & 0 & 0 & 0 \\
\hline Union & 2 & 10.781 & 0 & 0 & 0 & 0 & 0 \\
\hline & 3 & 10.781 & 0 & 0 & 0 & 0 & 0 \\
\hline & 4 & 10.781 & 0 & 0 & 0 & 0 & 0 \\
\hline & 5 & 10.781 & 0 & 0 & 0 & 0 & 0 \\
\hline CU $(1,2,3) \&$ & 1 & 10.745 & 0 & 0 & 0 & 0.265 & 0.265 \\
\hline CU $(4,5)$ & 2 & 10.745 & 0 & 0 & 0 & 0.265 & 0.265 \\
\hline & 3 & 10.745 & 0 & 0 & 0 & 0.265 & 0.265 \\
\hline & 4 & 10.693 & 0.266 & 0.266 & 0.266 & 0 & 0 \\
\hline & 5 & 10.693 & 0.266 & 0.266 & 0.266 & 0 & 0 \\
\hline
\end{tabular}

Table 2 reports outcomes in a 5-country world in which various combinations of countries create customs unions. It shows that in the "No CU" scenario, each country sets its own optimal tariff. When a customs union of countries 1 and 2 or CU $(1,2)$ is formed, members determine a common external tariff, 0.2658 , that maximizes the CU's welfare. When the coalition structure changes from $\mathrm{CU}(1,2)$ to $\mathrm{CU}(1,2,3)$, the optimal tariff of members of the enlarged customs union falls from 0.2658 to 0.2647 , but the optimal tariffs of nonmembers; i.e., countries 4 and 5 , remain unchanged at $0.2500{ }^{5}$ Optimal tariffs of countries 4 and 5 change only when they form a customs union.

Table 2 also provides an example where a grand customs union is a stable outcome even without the open regionalism rule since existing members of a customs union of any size would welcome new members because this will increase their welfare levels (a case where the rule is not binding). As Yi has pointed out, whether open regionalism rule is critical depends on the number of countries in the world as well as the substitution parameter $\mathrm{g}$. Sensitivity analysis on the maximum number of countries in the world with different values of $g$ and slopes of the

\footnotetext{
${ }^{5}$ The optimal tariff of a customs union is not a monotonic function of the number of members because there are two conflicting effects when a customs union expands. On the one hand an individual country would want to reduce its external tariffs since it eliminates tariffs on more imported goods as the CU expands and because it prefers a balanced consumption bundle to an unbalanced one. This is basically the "import sourcing" condition explained by Sinclair and Vines (1995). On the other hand, this country also considers other members' export profits to this country since it maximizes the joint welfare of member countries and hence would increase its external tariffs so that other members benefit through higher export profits to this country. Whether optimal tariff of members falls or rises as a customs union enlarges depends on the number of countries in the world. A detailed explanation is found in Yi (1996a)
} 
marginal cost curve are shown in Appendix 1. ${ }^{6}$

\section{Open Regionalism is Not Sufficient for Good}

We demonstrate now how the open regionalism rule may fail to work. To do so, we make changes to Yi's model in three stages (Table 3).

Table 3. Varying Yi's Model in 3 Stages

\begin{tabular}{|c|c|c|c|}
\hline Stage & Consumer Preferences & Production Technology & Type of Competition \\
\hline (Yi's model) & Quasilinear preferences & Constant marginal costs & Cournot competition \\
\hline 1 & Quasilinear preferences & $\begin{array}{c}\text { Increasing marginal } \\
\text { costs }\end{array}$ & Cournot competition \\
\hline 2 & $\begin{array}{l}\text { Constant elasticity of } \\
\text { substitution preferences }\end{array}$ & Constant marginal costs & $\begin{array}{l}\text { Cournot and Bertrand } \\
\text { competition }\end{array}$ \\
\hline 3 & $\begin{array}{l}\text { Constant elasticity of } \\
\text { substitution preferences }\end{array}$ & $\begin{array}{l}\text { Increasing marginal } \\
\text { costs }\end{array}$ & $\begin{array}{l}\text { Cournot and Bertrand } \\
\text { competition }\end{array}$ \\
\hline
\end{tabular}

\section{A. Stage 1: Increasing Marginal Costs}

Yi assumes a constant marginal cost of production in his model. We remove this Ricardian technology assumption (but retain the quasilinear preferences assumption) and replace it with an upward sloping marginal cost function $c=x+b^{*} Q_{j}$ (where $Q_{j}=\sum_{i=1}^{N} q_{i j}$ or the total output of

\footnotetext{
${ }^{6} \mathrm{Yi}$ assumes that countries are ex ante identical in endowment size. But even when countries are asymmetric in endowment size, results on tariffs, prices and quantities will be identical to the symmetric case. The only changes are on the utility levels and the consumption of numeraire good by a larger country. This is because with quasilinear preferences, a larger country; i.e., one with more endowment of the numeraire good, will not be any different from a smaller country in its demand for the non-numeraire good since demand for the non-numeraire good is independent of income. With a Ricardian technology, a large country behaves exactly like a small country since the terms of trade are fixed between countries as it does not have any ability to affect its terms of trade. As a result, Yi's claim that open regionalism is good under the symmetric case will continue to hold under asymmetric endowment size, provided that all other assumptions in the model are retained.
} 
good $j$ by country $j$ ). ${ }^{7}$ Putting an increasing MC function into this model is a convenient way to convert the straight-line production possibility frontier (PPF) in Yi's model into a concave PPF in order to reflect an increasing rate of product transformation (RPT) between the numeraire good and the differentiated good. ${ }^{8}$

The optimal tariff of a country / customs union is no longer independent of other countries'/ customs union's tariff when marginal cost is upward sloping even though consumer preferences are still quasilinear. Table 4 shows that when country 1 is allowed to set its optimal tariff, country 2's consumption of good 1 and 2 changes. Consumption of good 1 by country 2 falls because the tariff-induced increase in country 1's consumption raises 1's costs of production.

Table 4. Optimal Tariff of Country 1 when Country 2 is Passive - Increasing Marginal Costs

\begin{tabular}{|l|c|l|c|c|c|c|c|c|}
\hline $\begin{array}{c}\text { Trade } \\
\text { Scenario }\end{array}$ & Country & Welfare & $\begin{array}{c}\text { Tariff } \\
\text { on } \\
\text { Good 1 }\end{array}$ & $\begin{array}{c}\text { Tariff } \\
\text { on } \\
\text { Good 2 }\end{array}$ & $\begin{array}{c}\text { Price } \\
\text { of } \\
\text { Good 1 }\end{array}$ & $\begin{array}{c}\text { Price } \\
\text { of } \\
\text { Good 2 }\end{array}$ & $\begin{array}{c}\text { Consumption } \\
\text { of } \\
\text { Good 1 }\end{array}$ & $\begin{array}{c}\text { Consumption } \\
\text { of } \\
\text { Good 2 }\end{array}$ \\
\hline Free Trade & 1 & 10.592 & 0 & 0 & 1.400 & 1.400 & 0.400 & 0.400 \\
\hline $\begin{array}{l}\text { Country 1 sets } \\
\text { optimal tariff }\end{array}$ & 1 & 10.637 & 0 & 0.343 & 1.445 & 1.553 & 0.442 & 0.226 \\
\hline & 2 & 10.482 & 0 & 0 & 1.3995 & 1.393 & 0.396 & 0.409 \\
\hline
\end{tabular}

Optimal tariffs are interdependent in this case given that the marginal cost of producing the non-numeraire good is a positive function of output. When, say, country 1 sets a tariff on its imports from country 2, its consumption of imports falls while consumption of its home good rises. A fall in country 1's demand for good 2 reduces country 2's total output and its marginal cost of production. This leads to a fall in its price and hence good 2 becomes relatively cheaper than good 1 in country 2 . Country 2's consumption adjusts to this relative price change. Country 2's optimal tariff therefore depends on country 1's tariff level since it affects country 2's production equilibrium, not through income effect but through the effects on marginal cost and hence prices.

When marginal cost is upward sloping, the first order condition for profit maximization; i.e., Equation 4 becomes

$$
\alpha-\tau_{i j}-(2-\gamma) q_{i j}-\gamma Q_{i}=0
$$

\footnotetext{
We recalibrate the simulation model so that the same free trade equilibrium quantities of differentiated goods are retained as in our simulation of Yi's model.

${ }^{8}$ A concave PPF captures the characteristics of most production situations: diminishing returns, specialized input, or differing factor intensities between goods.
} 


$$
\begin{gathered}
\text { where } \alpha=a-c \text { and } c=x+b\left(\sum_{i} q_{i j}\right) \\
\Rightarrow \quad a-x-b\left(\sum_{i} q_{i j}\right)-\tau_{i j}-(2-\gamma) q_{i j}-\gamma Q_{i}=0
\end{gathered}
$$

In a two-country world, equation $(4 *)$ becomes

$$
\begin{aligned}
& \text { for country } 1 a-x-b\left(q_{11}+q_{21}\right)-\tau_{12}-(2-\gamma) q_{12}-\gamma Q_{1}=0 \\
& \text { for country } 2 a-x-b\left(q_{22}+q_{12}\right)-\tau_{21}-(2-\gamma) q_{21}-\gamma Q_{2}=0
\end{aligned}
$$

With marginal cost as a function of total output, Equations $4 * \mathrm{a}$ and $4 * \mathrm{~b}$ become interdependent. The equilibrium values of $q_{21}$ and $q_{12}$ are now interdependent, as well as those of $\tau_{12}$ and $\tau_{21}$. When, say, country 1 raises its tariff, $\tau_{12}$ on $q_{12}$ from Equation $4^{*} \mathrm{a}$, this will reduce $q_{12}$. When $q_{12}$ falls, Equation $4 *$ b shows that variables $q_{21}$ (country 2 's import from country 1 ), $q_{22}$ (country 2 's consumption of home good), and $\tau_{21}$ will adjust in order to reach a new equilibrium.

Table 5 shows simulation results of a world with five countries, all of which are active with tariffs as a policy tool.

Table 5. Five Countries in the World, Countries are Symmetric, Increasing Marginal Costs

\begin{tabular}{|c|c|l|l|l|l|l|l|}
\hline $\begin{array}{c}\text { Trade } \\
\text { Scenario }\end{array}$ & Country & Utility & \multicolumn{5}{|c|}{ Tariffs on Good } \\
\hline No CU & 1 & & 1 & 2 & \multicolumn{2}{c|}{3} & \multicolumn{1}{c|}{4} \\
\hline & 2 & 10.779 & 0 & 0.256 & 0.256 & 0.256 & 0.256 \\
\hline & 3 & 10.779 & 0.256 & 0.256 & 0 & 0.256 & 0.256 \\
\hline & 4 & 10.779 & 0.256 & 0.256 & 0.256 & 0 & 0.256 \\
\hline & 5 & 10.779 & 0.256 & 0.256 & 0.256 & 0.256 & 0 \\
\hline CU $(1,2)$ & 1 & 10.821 & 0 & 0 & 0.275 & 0.275 & 0.275 \\
\hline & 2 & 10.821 & 0 & 0 & 0.275 & 0.275 & 0.275 \\
\hline & 3 & 10.759 & 0.253 & 0.253 & 0 & 0.259 & 0.259 \\
\hline & 4 & 10.759 & 0.253 & 0.253 & 0.259 & 0 & 0.259 \\
\hline & 5 & 10.759 & 0.253 & 0.253 & 0.259 & 0.259 & 0 \\
\hline CU $(1,2,3)$ & 1 & 10.845 & 0 & 0 & 0 & 0.282 & 0.282 \\
\hline & 2 & 10.845 & 0 & 0 & 0 & 0.282 & 0.282 \\
\hline & 3 & 10.845 & 0 & 0 & 0 & 0.282 & 0.282 \\
\hline & 4 & 10.728 & 0.252 & 0.252 & 0.252 & 0 & 0.265 \\
\hline & 5 & 10.728 & 0.252 & 0.252 & 0.252 & 0.265 & 0 \\
\hline & 1 & 10.857 & 0 & 0 & 0 & 0 & 0.284 \\
\hline CU $(1,2,3,4)$ & 2 & 10.857 & 0 & 0 & 0 & 0 & 0.284 \\
\hline & & & & & & & \\
\hline
\end{tabular}




\begin{tabular}{|c|c|l|l|l|l|l|l|}
\hline $\begin{array}{c}\text { Trade } \\
\text { Scenario }\end{array}$ & Country & Utility & \multicolumn{5}{|c|}{ Tariffs on Good } \\
\hline & 3 & 10.857 & 0 & 0 & 0 & 0 & 0.284 \\
\hline & 4 & 10.857 & 0 & 0 & 0 & 0 & 0.284 \\
\hline & 5 & 10.688 & 0.255 & 0.255 & 0.255 & 0.255 & 0 \\
\hline Grand & 1 & 10.859 & 0 & 0 & 0 & 0 & 0 \\
Customs & & & & & & & \\
\hline Union & 2 & 10.859 & 0 & 0 & 0 & 0 & 0 \\
\hline & 3 & 10.859 & 0 & 0 & 0 & 0 & 0 \\
\hline & 4 & 10.859 & 0 & 0 & 0 & 0 & 0 \\
\hline & 5 & 10.859 & 0 & 0 & 0 & 0 & 0 \\
\hline CU $(1,2) \&$ & 1 & 10.772 & 0 & 0 & 0.273 & 0.273 & 0.273 \\
\hline CU $(3,4,5)$ & 2 & 10.772 & 0 & 0 & 0.273 & 0.273 & 0.273 \\
\hline & 3 & 10.826 & 0.279 & 0.279 & 0 & 0 & 0 \\
\hline & 4 & 10.826 & 0.279 & 0.279 & 0 & 0 & 0 \\
\hline & 5 & 10.826 & 0.279 & 0.279 & 0 & 0 & 0 \\
\hline
\end{tabular}

From Table 5 (contrast this with Table 2), the optimal tariff of a country/customs union depends not only on its relative size to the world but also the composition of coalition structures in the world. This is shown when we compare the coalition structures of a world with only one customs union, $\mathrm{CU}(1,2)$ and a world with two customs unions of $\mathrm{CU}(1,2)$ and $\mathrm{CU}(3,4,5)$. Tariffs set by members of CU $(1,2)$ fall from 0.275 (when countries 3,4 , and 5 are separate countries) to 0.273 (when countries 3,4 , and 5 form a customs union).

Further, the interdependence of countries' optimal tariffs shows some interesting results. The formation of CU $(1,2)$ raises the member's tariffs from a pre-CU level of 0.256 to postCU level of 0.275 . Non-members; i.e., countries 3, 4, and 5 lower their tariffs on imports from CU members (from 0.256 to 0.253 ) while tariffs between themselves are increased (from 0.256 to 0.259 ). This pattern where countries 3,4 , and 5 set higher tariffs on non-CU members than CU members can be explained by the "import sourcing condition" of Sinclair \& Vines (1995) in the following way: First, as a result of the formation of a CU between 1 and 2, consumption of home good of the CU; i.e., goods 1 and 2, increases due to the removal of intra-bloc tariffs and higher external tariffs set on non-CU goods. Increased consumption of goods 1 and 2 also means higher marginal cost of production (given an upward sloping marginal cost now) and thus higher prices. With this switch of consumption toward CU goods from non-CU goods, there is a fall in the consumption of goods 3,4 , and 5, which also means a fall in the marginal cost of production and thus a fall in prices. All these bring the world prices of goods 1 and 2 to be relatively higher than those of goods 3,4 , and 5 . Since a country prefers a balanced consumption bundle to an unbalanced one given the love-of-variety preferences, these non-CU 
countries, say country 3 , faced with two sources of imports, one from the $\mathrm{CU}$, which is more expensive, and the other from the non-CU countries, which is less expensive, will therefore set lower tariffs on CU goods and higher tariffs on non-CU goods. This pattern of non-CU countries setting higher tariffs on non-CU imports than tariffs on $\mathrm{CU}$ imports continues as the $\mathrm{CU}$ enlarges. Note that the average tariffs set by non-CU countries in all these trade scenarios stay around $0.255-0.256$. As the $\mathrm{CU}$ expands into $\mathrm{CU} 1,2,3$, 4, country 5 , which is now the only non-CU country in the world, sets higher tariffs on its imports (which are all sourced from CU countries) than the tariffs when the CU is comprised of countries 1,2 , and 3 . The reason for this seemingly unusual tariff pattern is simply because now there is only one source of import; i.e., they are all sourced from the $\mathrm{CU}$ of 1, 2, 3, 4 and hence the "import-sourcing condition" explained above disappears. Note that country 5's optimal tariff of 0.255 is roughly the same as the average tariffs set by the non-CU countries stated earlier.

It is interesting to note that even though now the optimal tariff of a country is dependent on other countries'/customs union's tariff level, Yi's qualitative results that open regionalism is good continues to hold because of the quasilinear preference assumption in the model. As long as quasilinear preferences are assumed in the model, there will be zero income effect on the consumption of non-numeraire good and hence even if we assume the model in Table 5 to have a larger country, the larger country will behave exactly the same as a smaller country would behave; i.e., by setting the same tariff. This means that even in the asymmetric country size world, a larger country will not be better off by staying out of a customs union and setting a Nash tariff. All countries will improve their own welfare levels by joining a customs union and a grand customs union will be a stable coalition structure.

\section{B. Stage 2: CES Preferences}

In this model, the assumption of Ricardian technology is retained but that of quasilinear preferences is replaced with constant elasticity of substitution (CES) preferences. The utility function has two levels. At the top level, a consumer allocates his budget between the consumption of the numeraire good MM, a homogeneous good, and the consumption of an aggregate of the non-numeraire good TG, a differentiated good. The lower level involves the distribution of consumption of the non-numeraire good among the individual varieties of the differentiated good q. These two levels of utility functions can be combined into a single level if the elasticities of substitution of the two levels are the same. If this assumption is made, the numeraire good is then treated similarly as one of the varieties of the differentiated good. But we want to treat these two goods as different types of goods, which is similar to Yi's assumption, by assuming that $\alpha<\theta$ (i.e., the elasticity of substitution at the sub-level is higher than the one at the top level). The top-level utility and sub-utility functions are as follows: 


$$
\begin{aligned}
W_{i} & =\left(b_{i}^{(1-\alpha)} T G_{i}{ }^{\alpha}+\left(1-b_{i}\right)^{(1-\alpha)} M M_{i}^{\alpha}\right)^{1 / \alpha} \\
T G_{i} & =\left(\sum_{j} a_{j}^{i(1-\theta)} q_{j}^{i \theta}\right)^{1 / \theta}
\end{aligned}
$$

Given this love-of-variety type preferences and that $0<\alpha<1$, each good is consumed in every country which means that each country exports part of its own variety of differentiated good in exchange for some imports of all other varieties of the differentiated good.

With a CES utility function, the demand function for a differentiated product, $j$, is as follows:

$$
q_{j}=\frac{I}{P} a_{j}^{\theta}\left(\frac{p_{j}}{P}\right)^{-\theta}
$$

where $I$ : budget allocated for the consumption of differentiated good

$P$ : price index for good TG

$p_{j}:$ price of good $j$

This demand function shows that demand for $q_{j}$ is an increasing function of $I$, income, and decreasing for $p_{j}$, the price of one's own good.

We consider both Cournot and Bertrand cases. In the Cournot case, each firm maximizes its profit by setting its output, assuming other firms' output levels are constant; in the Bertrand case, each firm sets its price to maximize profit, assuming other firms' prices are constant.

Table 6 shows simulation results of a model with two countries in the world. When countries are symmetric in size; i.e., there is equal endowment of the numeraire good, it is expected that both countries are better off under global free trade than in a world with restricted trade where all countries set Nash tariffs. But even when countries are asymmetric in size where country 1 is twice as large country 2 in its endowment of the numeraire good, the optimal tariff of country 1 is the same as the optimal tariff of country 2 . Country 1 , although being larger, does not have the capability to improve its terms of trade.

\footnotetext{
${ }^{9}$ With a CES demand function in this model, the demand curve can be steeper than its marginal revenue curve. Appendix 2 provides further explanations.

${ }^{10}$ We also observe that the Nash tariff levels of 0.031 under Bertrand competition and 0.032 under Cournot competition are notably lower compared with other studies reported in the literature that also use CES utility function for example, Krugman (1991). This outcome of low tariffs in our model is due to the presence of a negative tariff component in the overall optimal tariff. See explanation on the "rent-extraction" type tariff in Appendix 3.
} 
Table 6. Welfare and Tariff Levels Under "No Coalition" and "Global Free Trade"

\begin{tabular}{|c|c|c|c|c|c|c|c|c|}
\hline $\begin{array}{l}\text { Country's } \\
\text { endowments }\end{array}$ & \multicolumn{4}{|l|}{$\begin{array}{l}1: 10 \\
2: 10\end{array}$} & \multicolumn{4}{|l|}{$\begin{array}{l}1: 20 \\
2: 10\end{array}$} \\
\hline $\begin{array}{l}\text { Trade } \\
\text { Scenario }\end{array}$ & \multicolumn{2}{|c|}{ Welfare } & \multicolumn{2}{|c|}{ Tariff } & \multicolumn{2}{|c|}{ Welfare } & \multicolumn{2}{|c|}{ Tariff } \\
\hline \multirow[t]{3}{*}{ No Coalition } & Bertrand & $\underline{\text { Cournot }}$ & Bertrand & $\underline{\text { Cournot }}$ & Bertrand & Cournot & $\underline{\text { Bertrand }}$ & Cournot \\
\hline & 1: 9.618 & 9.567 & 0.031 & 0.032 & 18.848 & 18.740 & 0.031 & 0.032 \\
\hline & 2: 9.618 & 9.567 & 0.031 & 0.032 & 10.006 & 9.962 & 0.031 & 0.032 \\
\hline Global Free & 1: 9.648 & 9.600 & 0 & 0 & 18.878 & 18.772 & 0 & 0 \\
\hline Trade & 2: 9.648 & 9.600 & 0 & 0 & 10.067 & 10.027 & 0 & 0 \\
\hline
\end{tabular}

The reason that the larger country sets the same optimal tariff as the small country is the Ricardian technology assumption in the model. When marginal cost is constant, the ability of a large country to improve its terms of trade disappears because every country faces a flat foreign marginal cost in the import market, which is similar to a small country assumption.

Table 6 also shows that as the endowment of one country, country 1, increases, the welfare level of not only this country, but also the other country increases. As country 1's endowment of numeraire good rises, it increases its exports of numeraire good to country 2 at a price of one (as this is the numeraire good) and at the same time increases its imports of country 2's differentiated good at a price that exceeds one (because of a price markup). This exchange benefits country 2 and hence country 2 gains from a rise in country 1's endowment.

\section{Stage 3: Increasing Marginal Costs and CES Preferences}

Table 7 shows the model with increasing marginal costs and CES preferences for the case of 2 countries in the world. Three combinations of country sizes are considered. When countries are symmetric in size, all countries are better off under global free trade and a grand customs union can be a stable outcome. But when countries are asymmetric in size, a grand customs union may not provide a stable outcome. 
Table 7. Welfare and Tariff Levels Under "No Coalition" and "Global Free Trade" CES Utility and Increasing Marginal Costs

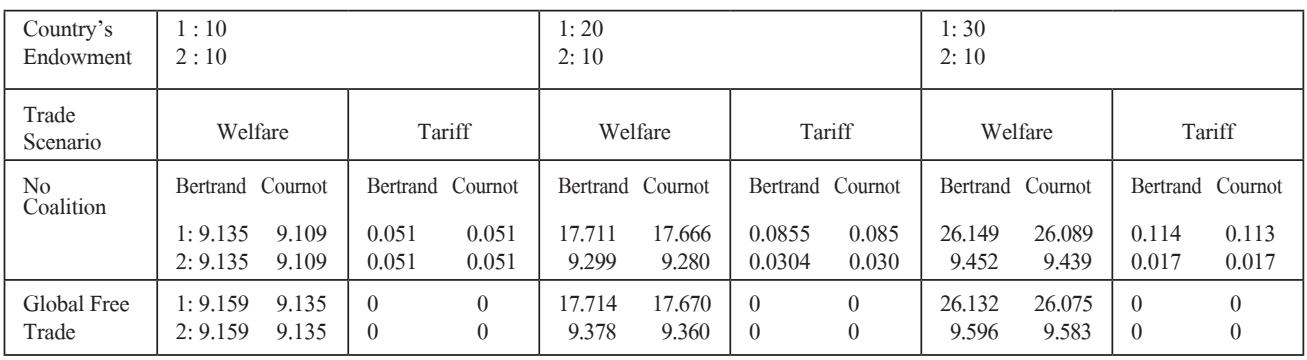

When the larger country is three times larger than the smaller country, it prefers to avoid a global free trade since its welfare level is higher under "No Coalition." Qualitative results are the same for both Bertrand and Cournot competitions. This result is essentially the large country case for optimal tariff as demonstrated by Johnson (1954) that a country may gain by imposing a tariff even if other countries retaliate.

Table 8 reports the Bertrand case of a 5-country world model where country 1 is endowed with 60 units of numeraire good and countries 2 to 4 have 10 each. The move into an asymmetric world raises issues of coalition formation (e.g., bargaining procedure discussed by Aghion, Antrás, and Helpman, 2007; Siedmann, 2009). Our focus, however, is not on the process of coalition formation/expansion, but on the presence (or absence) of stability of a coalition once it is formed. Hence, the type of coalition game, whether it is a simultaneous or sequential move game, is not particularly important here.

The scenarios listed in Table 8 effectively cover all possible outcomes of a simultaneousmove game of an asymmetric world where only one CU exists. ${ }^{11}$ Alternatively it can also be seen as a sequential-move game where in the beginning, there is no customs union in the world (no CU) then country 1 announces an "address," $P_{l}$. After observing $P_{l}$, country 2 announces $P_{2}$, and so on up to $P_{5}$. The process is repeated; i.e., country 1 announces $P_{1}$ again after observing $P_{5}$, and so on until an equilibrium coalition structure is reached. To illustrate, $P_{1}$ can be a proposed address of any of the trade scenarios in Table 8 . Say $P_{1}$ is CU $(1,2)$. After observing $P_{1}$, country 2 makes its announcement, $P_{2}$ as CU $(1,2)$. Country 3 will then announce $P_{3}$ as CU $(1,2,3)$ and $P_{4}$ will be $\mathrm{CU}(1,2,3,4)$ followed by $P_{5}$ that is a grand CU. But when country 1 reconsiders its $P_{1}$ after observing $P_{5}$, it will change to $\mathrm{CU}(2,3,4,5)$; that is, country 1 leaves the coalition. Given this rule of sequential move, $\mathrm{CU}(2,3,4,5)$ may be a stable coalition.

The sequence of country order can be changed; that is, country 1 need not be the first to

\footnotetext{
${ }^{11}$ A world with two CUs; for example, a world with $\mathrm{CU}(1,2)$ \& $\mathrm{CU}(3,4,5)$ or a world with $\mathrm{CU}(2,3) \& \mathrm{CU}(4,5) \& 1$ as an individual, is excluded from the list for simplicity. This does not affect our conclusion since our question is on whether a grand CU is a stable coalition.
} 
announce but it can be anywhere in the order of announcement. In any case, when the game reaches country 1 's turn to consider its $P_{1}$ if the address reaches the grand $\mathrm{CU}$, country 1 will always choose to leave the grand $\mathrm{CU}$, which is never an equilibrium coalition structure.

This example shows that a grand customs union is unlikely to be the Nash equilibrium customs-union structure even if the open regionalism rule is adopted. This is because country 1 's welfare level is higher when all countries set Nash tariffs than when they are under global free trade. $^{12}$

Table 8. CES Utility and Identical Increasing Marginal Costs (Bertrand Competition)

\begin{tabular}{|c|c|c|c|c|c|c|c|}
\hline Trade Scenario & Country & Welfare & $\begin{array}{c}\text { Tariffs on Good } \\
1\end{array}$ & 2 & 3 & 4 & 5 \\
\hline \multirow[t]{5}{*}{ No CU } & $1(60)$ & 51.608 & 0 & 0.038 & 0.038 & 0.038 & 0.038 \\
\hline & $2(10)$ & 9.387 & -0.023 & 0 & -0.010 & -0.010 & -0.010 \\
\hline & $3(10)$ & 9.387 & -0.023 & -0.010 & 0 & -0.010 & -0.010 \\
\hline & $4(10)$ & 9.387 & -0.023 & -0.010 & -0.010 & 0 & -0.010 \\
\hline & $5(10)$ & 9.387 & -0.023 & -0.010 & -0.010 & -0.010 & 0 \\
\hline \multirow[t]{5}{*}{$\mathrm{CU}(1,2)$ only } & 1 & 52.610 & 0 & 0 & 0.069 & 0.069 & 0.069 \\
\hline & 2 & 9.420 & 0 & 0 & 0.069 & 0.069 & 0.069 \\
\hline & 3 & 9.358 & -0.023 & -0.011 & 0 & -0.009 & -0.009 \\
\hline & 4 & 9.358 & -0.023 & -0.011 & -0.009 & 0 & -0.009 \\
\hline & 5 & 9.358 & -0.023 & -0.011 & -0.009 & -0.009 & 0 \\
\hline \multirow{5}{*}{$\begin{array}{l}\mathrm{CU}(1,2,3) \\
\text { only }\end{array}$} & 1 & 51.608 & 0 & 0 & 0 & 0.096 & 0.096 \\
\hline & 2 & 9.418 & 0 & 0 & 0 & 0.096 & 0.096 \\
\hline & 3 & 9.418 & 0 & 0 & 0 & 0.096 & 0.096 \\
\hline & 4 & 9.321 & -0.022 & -0.010 & -0.010 & 0 & -0.007 \\
\hline & 5 & 9.321 & -0.022 & -0.010 & -0.010 & -0.007 & 0 \\
\hline \multirow{5}{*}{$\begin{array}{l}\mathrm{CU}(1,2,3,4) \\
\text { only }\end{array}$} & 1 & 51.606 & 0 & 0 & 0 & 0 & 0.120 \\
\hline & 2 & 9.413 & 0 & 0 & 0 & 0 & 0.120 \\
\hline & 3 & 9.413 & 0 & 0 & 0 & 0 & 0.120 \\
\hline & 4 & 9.413 & 0 & 0 & 0 & 0 & 0.120 \\
\hline & 5 & 9.277 & -0.021 & -0.009 & -0.009 & -0.009 & 0 \\
\hline \multirow[t]{3}{*}{$\mathrm{CU}(2,3)$ only } & 1 & 51.611 & 0 & 0.038 & 0.038 & 0.039 & 0.039 \\
\hline & 2 & 9.386 & -0.002 & 0 & 0 & 0.017 & 0.017 \\
\hline & 3 & 9.386 & -0.002 & 0 & 0 & 0.017 & 0.017 \\
\hline
\end{tabular}

${ }^{12}$ Results for the Cournot-type competition are similar to the Bertrand case. 


\begin{tabular}{|l|c|c|c|c|c|c|c|}
\hline Trade Scenario & Country & Welfare & $\begin{array}{c}\text { Tariffs on Good } \\
1\end{array}$ & \multicolumn{4}{|c|}{4} \\
\hline & 4 & 9.380 & -0.023 & -0.010 & -0.010 & 0 & -0.010 \\
\hline & 5 & 9.380 & -0.023 & -0.010 & -0.010 & -0.010 & 0 \\
\hline $\begin{array}{l}\text { CU }(2,3,4) \\
\text { only }\end{array}$ & 1 & 51.611 & 0 & 0.038 & 0.038 & 0.038 & 0.040 \\
\hline & 2 & 9.385 & 0.016 & 0 & 0 & 0 & 0.041 \\
\hline & 3 & 9.385 & 0.016 & 0 & 0 & 0 & 0.041 \\
\hline & 4 & 9.385 & 0.016 & 0 & 0 & 0 & 0.041 \\
\hline & 5 & 9.366 & -0.023 & -0.009 & -0.009 & -0.009 & 0 \\
\hline $\begin{array}{l}\text { CU }(2,3,4,5) \\
\text { only }\end{array}$ & 1 & 51.604 & 0 & 0.038 & 0.038 & 0.038 & 0.038 \\
\hline & 2 & 9.383 & 0.029 & 0 & 0 & 0 & 0 \\
\hline & 3 & 9.383 & 0.029 & 0 & 0 & 0 & 0 \\
\hline & 4 & 9.383 & 0.029 & 0 & 0 & 0 & 0 \\
\hline & 5 & 9.383 & 0.029 & 0 & 0 & 0 & 0 \\
\hline $\begin{array}{l}\text { Grand } \\
\text { Customs }\end{array}$ & 1 & 51.602 & 0 & 0 & 0 & 0 & 0 \\
\hline Union & 2 & 9.403 & 0 & 0 & 0 & 0 & 0 \\
\hline & 3 & 9.403 & 0 & 0 & 0 & 0 & 0 \\
\hline & 4 & 9.403 & 0 & 0 & 0 & 0 & 0 \\
\hline & 5 & 9.403 & 0 & 0 & 0 & 0 & 0 \\
\hline
\end{tabular}

Note: Marginal cost functions for all countries are identical and increasing with output: $c=1+0.1 \sum q$, where $\sum q$ : total output of the individual variety of the differentiated good. $\theta=0.8 .^{13}$

For a small country such as country 2 , the best outcome would be that it is the only country that forms a customs union with the large country, country 1 (trade scenario CU $(1,2)$ in the table). But CU $(1,2)$ cannot be a stable equilibrium structure under open regionalism where membership of a customs union is open to outsiders. Other small countries will join to increase their welfare levels. As more small countries join in, the large country, country 1, will find its position compromised and hence will find a reason to leave the union.

Welfare levels in the table also suggest that there is no incentive for small countries to form

${ }^{13}$ The elasticity of substitution (e.o.s.) in this case is $=1 /(1-\theta)=5$. Changing the e.o.s. value in the model has different effects on each of the four components of the optimal tariff listed in Appendix 3. To mention briefly, an increase in e.o.s. (i) reduces the "Gros-type" tariff since higher e.o.s. means a smaller gap between price and $\mathrm{MC}$; hence, the Gros-type tariff needs to reflect the true relative cost between home and foreign goods is reduced (ii) diminishes the "rent-extraction" type tariff as this negative component of tariff should diminish and eventually disappear as e.o.s. increases since a flatter demand curve means smaller difference in slopes between the demand and marginal revenue curves (iii) reduces the "marginal-import-cost-type" tariff since flatter demand creates a smaller difference between $\mathrm{MC}$ and marginal import cost (iv) reduces the "export-tax-equivalent-type" tariff since less tariff is needed to extract the potential monopoly profit as well as to correct the wrongly perceived demand function since the perceived and actual demand functions converge. Sensitivity tests on e.o.s. values 5-10 have been conducted and all lead to a similar conclusion. Results are available upon request. 
customs union among themselves as their welfare levels are higher when all countries set Nash tariffs than any customs union structures among the small countries. The reason for this is that all the small countries prefer to subsidize their imports; i.e., set negative tariffs under Nash equilibrium. But when some or all the small countries form customs union, they are constrained to set zero tariffs among members. This zero-tariff constraint changes the optimal tariffs on nonmember countries (causing positive tariffs) and is actually welfare-reducing.

We note that some of the Nash tariffs set by small countries in both tables are negative with CES utility preferences. A negative Nash tariff is possible when a country is so small relative to another country that the rationale for an import subsidy (due to having a flatter marginal revenue curve than its demand) outweighs all other reasons for a positive tariff (see Appendix $3)$.

We also note that the welfare level of the large country, country 1 , is better off when there is a $\mathrm{CU}$ of some of the small countries; i.e., $\mathrm{CU}(2,3)$ and $\mathrm{CU}(2,3,4)$, compared when all small countries form a CU and when there is no CU in the world where each sets Nash tariffs. This is because the formation of $\mathrm{CU}$ among some of the small countries forces the prices of the non - CU small countries to fall as a result of trade diversion. This enables the large country to increase its tariff on imports from non - CU small countries.

\section{Effects of Varying Marginal Cost Slope}

The previous section demonstrates that a sufficiently larger country prefers to stay out of a customs union; hence, a grand customs union is not an equilibrium coalition structure. Table 8 gives an example of a large country that owns 60 percent of the world's endowment, but different marginal cost parameters would imply different thresholds.

We examine the effects of changing the slope of marginal cost function, $b$, on the optimal tariff of a country. An increase in $b$, ceteris paribus, raises a country's optimal tariff due to a rise in the marginal-import-cost-type tariff. As a result, the minimum size of the larger country needed, $s$, in order for it to prefer staying out of a customs union and hence not having grand customs union as equilibrium, falls as the slope of the marginal cost function increases. Table 9 summarizes the effect. 
Table 9. Effects of Varying $b$ on $s$

\begin{tabular}{|c|c|}
\hline$b$ (slope of marginal cost function) & $s$ (as percentage of the world's endowment) \\
\hline 0.1 & 60 \\
\hline 0.2 & 44 \\
\hline 0.3 & 40 \\
\hline 0.4 & 39 \\
\hline 0.5 & 38 \\
\hline 0.6 & 37 \\
\hline 0.7 & 37 \\
\hline 0.8 & 37 \\
\hline 0.9 & 37 \\
\hline 1.0 & 36 \\
\hline
\end{tabular}

\section{Concluding Remarks}

Quasilinear preferences and constant marginal costs are standard assumptions in the regionalism literature (examples of recent works include Chen and Joshi, 2010; Mrazova, 2010; Oladi and Beladi, 2008; Ornelas, 2005 a, b). As Ornelas (2005a) noted, this standard treatment may pose some important restrictions (e.g., on the external tariffs of FTA). This paper shows what may happen when this standard treatment is removed.

This paper has explained in detail why open regionalism rule works in Yi's model and in what conditions the rule does not work. This paper demonstrates that Yi's conclusion that open regionalism rule is good is confined to his unique pair of assumptions; i.e., constant marginal cost and quasilinear preferences. His claim collapses once these assumptions are replaced with a concave production possibility frontier and CES preferences in a world with asymmetric country sizes. The present paper examines the customs union case. Yi (1998) shows that if we move to the case of FTA, the open regionalism story falls apart even without our modifications.

The construction and assumptions of this model, where all goods are tradable and one of them (the numeraire good) is traded freely (i.e., tariff is zero on this good plus there are love-ofvariety preferences), inherently suppress the optimal tariff levels on the non-numeraire goods. As a result, a country in such model will have less incentive to stay out of a CU and hence a grand customs union is more likely to occur. Nevertheless, this paper demonstrates that even under such circumstances, a grand customs union may still not be the equilibrium coalition. A model with a non-tradable sector or all goods that are subject to tariffs will yield higher optimal tariffs, thereby leading to stronger incentives for countries to stay out of a CU and thus less likely to have a grand customs union. 
In the real world comprised of countries that are asymmetric in size, production technologies that are better represented by concave production possibility curves and many non-tradable goods, Yi's result on the open regionalism rule is perhaps too optimistic. The simulation exercise in this paper, albeit a particular case, provides a countercase that demonstrates that open regionalism rule does not ensure trade blocs will be stepping stones toward global free trade even in a simple rarified theoretical world.

Received 27 April 2011, Accepted 30 June 2012

\section{References}

Aghion, P., Antrás, P. and Helpman, E. (2007). Negotiating free trade, Journal of International Economics 73, pp1 -30 .

Bergsten, C. (1997). Open regionalism, World Economy, 20, pp545-565.

Bhagwati, J. (2006), Why Asia must opt for open regionalism on trade, FT.com, Financial Times, at http:// www.ft.com, accessed on $28^{\text {th }}$ September 2009.

Chen, M.X. and S. Joshi (2010), Third-country effects on the formation of free trade agreements, Journal of International Economics, Vol.82, pp 238 - 248.

Garnaut, R. (2004), A new open regionalism in the Asia Pacific, paper presented at the International Conference on World Economy, Colima, Mexico, 25 November, 2004.

Garnaut, R. and Vines, D. (2007). Regional free-trade areas: sorting out the tangled spaghetti, Oxford Review of Economy Policy, Vol23, No. 3, pp 508-527.

Gros, D. (1987), A note on the optimal tariff, retaliation and the welfare loss from tariff wars in a framework with intra-industry trade, Journal of International Economics 23, pp357-67.

Helpman, E. and Krugman, P.R. (1989), Trade Policy and Market Structure (London: MIT Press).

Johnson, H.G. (1954), Optimum tariffs and retaliation, The Review of Economic Studies, VolXXI, pp142-153.

Krugman, P.R. (1991), Is bilateralism bad? in Helpman, E. and A. Razin, eds., International Trade and Trade Policy (London: MIT Press).

Lerner, A.P. (1936), The symmetry between import and export taxes, Economica, 3, pp306-313.

Mrázová, M. (2010), Trade agreements when profits matter, paper presented at University of Nottingham GEP Seminar, 1 Nov 2010, at http://www.monikamrazova.com/index.php?id=Research\&img=2.

Oladi, R. and Beladi, H. (2008), Is regionalism viable? A case for global free trade, Review of International Economics, Vol 16(2), pp293 - 300.

Ornelas, E. (2005a), Endogenous free trade agreements and the multilateral trading system, Journal of International Economics, Vol67, pp471- 491.

(2005b), Trade creating free trade areas and the undermining of multilateralism, European Economic Review, 49(7), 1717 - 1735. 
Siedmann, D.J. (2009) Preferential trading arrangements as strategic positioning, Journal International Economics, Vol. 79, pp143-159

Sinclair, P. and Vines, D. (1995), Bigger trade blocs need not entail more protection, mimeo, University of Birmingham.

Varian, H.R. (1992), Microeconomic Analysis, $3^{\text {rd }}$ ed. (New York and London: W.W. Norton \& Company).

Yi, S.S. (1996a), Endogenous formation of customs unions under imperfect competition: open regionalism is good, Journal of International Economics, Vol.41, pp 153-177.

(1996b), Open regionalism and world welfare, Eastern Economic Journal, Vol. 22, No. 4.

(2000), Free-trade areas and welfare: an equilibrium analysis, Review of International Economics, Vol.8, No.2, pp336-347. 


\section{Appendices}

Appendix 1: Sensitivity test on the maximum number of countries in the world where a grand customs union is a stable outcome without open regionalism rule when MC slope increases

In Yi's model, whether open regionalism rule matters in ensuring a stable outcome of a grand customs union depends on the substitution parameter, $\gamma$, and the number of countries in the world, N. Let $\mathrm{N}^{*}$ be the maximum number of countries that the world can contain and still have a stable outcome of a grand customs union without open regionalism rule. Yi has shown that $\mathrm{N}^{*}$ is small for all values of $\gamma$. Sensitivity analysis is made on $\mathrm{N}^{*}$ for Model 1 (i.e., stage 1 which replaces the Ricardian technology with increasing marginal cost). We recalibrate the model to the same initial free trade quantities each time when the slope of the marginal cost function, $b$, increases by adjusting the intercept, $x$.

$$
\text { Let } c=x+b\left(\sum_{i} q_{i j}\right)
$$

where $\quad c$ : marginal cost

$x$ : intercept of the marginal cost function

b: slope

$\sum_{i} q_{i j}:$ total output of the differentiated good

Three values of $b$; i.e., $0,0.1$, and 0.9 are chosen. $b=0$ is Yi's case while $b=0.1$ and 0.9 are for the case of increasing marginal cost. Three values are sufficient to show the effects of $b$ on $\mathrm{N}^{*}$. The re-calibration means that the elasticity of marginal cost with respect to quantity varies slightly over cases. For example, a 5-country world with $\gamma=0.5, b=0.1$ gives a cost elasticity of 0.099 and $b=0.9$ gives an elasticity of 0.347 . A 7-country world with $\gamma=0.5, b=0.1$ gives an elasticity of 0.109 while $b=0.9$ gives 0.356 .

Table A1: N*, Maximum Number of Countries in the World where a Grand Customs Union is a Stable Outcome even without the Open Regionalism Rule

\begin{tabular}{|c|c|c|c|}
\hline$b$ & $\gamma=1$ & $\gamma=0.5$ & $\gamma=0.3$ \\
\hline 0 (from Yi) & 4 & 6 & 8 \\
\hline 0.1 & 4 & 5 & 6 \\
\hline 0.9 & 3 & 3 & 3 \\
\hline
\end{tabular}

Results in Table A1 show that as the slope of the marginal cost increases, $\mathrm{N}^{*}$ falls for all values of $\gamma$ and the value of $\mathrm{N}^{*}$ becomes less sensitive to the value of $\gamma$ as the slope of marginal cost 
curve increases.

The intuition behind this result is as follows. For an existing member of a customs union, if it accepts a new member into the $\mathrm{CU}$, it gains by being able to buy the variety of the differentiated good from the new member at lower cost since there is zero tariff now. If it rejects a new member and continues to set Nash tariffs, it benefits from foreign rent extraction through optimal tariffs. Thus, whether the existing member would welcome a new member depends on these two effects. If the benefits from freer trade outweigh the gain from foreign rent extraction, a new member is welcome. Given $\gamma$ and $b$, as the number of countries in the world, N, increases, the size of a customs union of N-1 members relative to the left-out country rises and therefore the gain from foreign rent extraction increases while the benefits from freer trade fall. There is a critical value of $\mathrm{N}$ where the benefits from freer trade outweigh the gain from foreign rent extraction and hence a new member is welcome, which means there is a strong incentive for countries to form a grand customs union.

As the value of the substitution parameter, $\gamma$, falls, goods between countries become less substitutable. Since consumers value varieties in their consumption, the benefits from freer trade increase as $\gamma$ falls and hence existing members are more willing to accept new members. This also means that it is more likely to achieve a grand customs union in the absence of the open regionalism rule. The critical value, $\mathrm{N}^{*}$, therefore increases as $\mathrm{g}$ falls.

The reason why $\mathrm{N}^{*}$ falls as the slope of $\mathrm{MC}$ and $b$ rises is that when $\mathrm{MC}$ is horizontal, the cost of one extra unit of imported good and the cost of one extra unit of domestic good are the same. But when MC slopes upward, the marginal cost of acquiring one extra unit of imported good is higher than the marginal cost of acquiring one extra unit of domestic good. The benefits from foreign rent extraction increase as the slope of MC increases. The critical value, $\mathrm{N}^{*}$, therefore falls as $b$ increases.

Note that here we assume the slopes of MC curves are the same across all countries. The value of $\mathrm{N}^{*}$ changes if asymmetry in MC slopes between countries is introduced.

\section{Appendix 2: Deriving Marginal Revenue Function of a CES Demand}

We show here that with a CES utility function, the demand curve can be steeper than its marginal revenue curve.

A CES demand function for good 1 has the following form:

$q_{1}=a_{1}^{\sigma} \cdot\left(p_{1} / P\right)^{-\sigma} \cdot M / P$

where $q_{1}$ : quantity demanded for good 1

$a_{1}$ : CES share parameter for good 1 
$p_{1}:$ price of good 1

$\sigma$ : elasticity of substitution, $1<\sigma \leq \infty$

$M$ : income

$$
\text { and } P=\left(\sum_{k=1}^{n} a_{k}^{\sigma} \cdot p_{k}^{1-\sigma}\right)^{1 / 1-\sigma}
$$

Total revenue of selling $q_{1}$ is

$$
\begin{aligned}
& R_{1}=p_{1} \cdot q_{1} \\
& =a_{1}^{\sigma}\left(\frac{p_{1}^{1-\sigma}}{P^{\sigma}}\right) \cdot \frac{M}{P} \\
& =a_{1}^{\sigma}\left(\frac{p_{1}}{P}\right)^{1-\sigma} \cdot M \\
& =a_{1}^{\sigma} \cdot p_{1}^{1-\sigma} \cdot P^{\sigma-1} \cdot M \\
& =a_{1}^{\sigma} \cdot p_{1}^{1-\sigma} \cdot\left(\sum_{k=1}^{n} a_{k}^{\sigma} p_{k}^{1-\sigma}\right)^{\frac{\sigma-1}{1-\sigma}} \cdot M \\
& =a_{1}^{\sigma} \cdot p_{1}^{1-\sigma} \cdot\left(\sum_{k=1}^{n} a_{k}^{\sigma} p_{k}^{1-\sigma}\right)^{\frac{-(1-\sigma)}{1-\sigma}} \cdot M \\
& =a_{1}^{\sigma} \cdot p_{1}^{1-\sigma} \cdot\left(\sum_{k=1}^{n} a_{k}^{\sigma} p_{k}^{1-\sigma}\right)^{-1} \cdot M
\end{aligned}
$$

$d R_{1} / d p_{1}$

$$
\begin{aligned}
& =a_{1}^{\sigma}(1-\sigma) p_{1}^{-\sigma} \cdot M \cdot\left(\sum_{k=1}^{n} a_{k}^{\sigma} \cdot p_{k}^{1-\sigma}\right)^{-1}+a_{1}^{\sigma} \cdot p_{1}^{1-\sigma} \cdot M(-1)\left(\sum_{k=1}^{n} a_{k}^{\sigma} \cdot p_{k}^{1-\sigma}\right)^{-2} \cdot a_{1}^{\sigma}(1-\sigma) p_{1}^{-\sigma} \\
& =a_{1}^{\sigma}(1-\sigma) p_{1}^{-\sigma} \cdot M \cdot\left(\sum_{k=1}^{n} a_{k}^{\sigma} \cdot p_{k}^{1-\sigma}\right)^{-1} \cdot\left[1-a_{1}^{\sigma} \cdot p_{1}^{1-\sigma} \cdot\left(\sum_{k=1}^{n} a_{k}^{\sigma} \cdot p_{k}^{1-\sigma}\right)^{-1}\right] \\
& q_{1}=a_{1}^{\sigma} \cdot p_{1}^{-\sigma} \cdot\left(\sum_{k=1}^{n} a_{k}^{\sigma} \cdot p_{k}^{1-\sigma}\right)^{-1} \cdot M
\end{aligned}
$$


$d q_{1} / d p_{1}$

$=a_{1}^{\sigma}(-\sigma) p_{1}^{-\sigma-1} \cdot M \cdot\left(\sum_{k=1}^{n} a_{k}^{\sigma} \cdot p_{k}^{1-\sigma}\right)^{-1}+a_{1}^{\sigma} \cdot p_{1}^{-\sigma} \cdot M(-1)\left(\sum_{k=1}^{n} a_{k}^{\sigma} \cdot p_{k}^{1-\sigma}\right)^{-2} \cdot a_{1}^{\sigma}(1-\sigma) p_{1}^{-\sigma}$

$=a_{1}^{\sigma} \cdot p_{1}^{-\sigma} \cdot M \cdot\left(\sum_{k=1}^{n} a_{k}^{\sigma} \cdot p_{k}^{1-\sigma}\right)^{-1} \cdot\left[(-\sigma) p_{1}^{-1}-a_{1}^{\sigma}(1-\sigma) p_{1}^{-\sigma} \cdot\left(\sum_{k=1}^{n} a_{k}^{\sigma} \cdot p_{k}^{1-\sigma}\right)^{-1}\right]$

Marginal revenue $M R_{1}=d R_{1} / d q_{1}=d R_{l} / d p_{1} \cdot d p_{1} / d q_{1}=d R_{l} / d p_{1} \cdot\left(d q_{1} / d p_{1}\right)^{-1}$

$$
=\frac{(1-\sigma)\left(1-a_{1}^{\sigma} \cdot p_{1}^{1-\sigma}\left[\sum_{k=1}^{n} a_{k}^{\sigma} \cdot p_{k}^{1-\sigma}\right]^{-1}\right)}{\left((-\sigma) p_{1}^{-1}-a_{1}^{\sigma}(1-\sigma) p_{1}^{-\sigma} \cdot\left[\sum_{k=1}^{n} a_{k}^{\sigma} \cdot p_{k}^{1-\sigma}\right]^{-1}\right)}
$$

The slope of $M R_{1} d M R_{1} / d q_{1}=d M R_{1} / d p_{1} \cdot d p_{1} / d q_{1}$

$d p_{I} / d q_{1}$ is the slope of demand.

If $0<d M R_{I} / d p_{1}<1$, then $d M R_{I} / d q_{1}<d p_{1} / d q_{1} \quad$ (marginal revenue is flatter than demand)

If $d M R_{1} / d p_{1}>1$, then $d M R_{l} / d q_{1}>d p_{l} / d q_{1}$ (marginal revenue is steeper than demand)

If $d M R_{l} / d p_{1}<0$, then $d M R_{l} / d q_{1}>0 \quad$ (marginal revenue slopes upward)

To see how $d M R_{1} / d p_{1}$ changes with $p_{1}$, simulations are made on a range of $p_{1}$, given $p_{2}=1$, $a_{1}=0.5, a_{2}=0.5, M=10, s=5$, assuming there are two goods. The values chosen for $a_{1}, a_{2}, M$, and $s$ are based on the parameters in our main model. The results are shown in Table A2.

Table A2: Examining How $D M R / d p_{1}$ changes with $p_{1}$

\begin{tabular}{|l|c|c|c|}
\hline$p_{I}$ & $d M R_{I} / d p_{I}$ & $d p_{I} / d q_{I}$ & $d M R_{I} / d q_{I}$ \\
\hline 1 & 0.237 & -0.065 & -0.015 \\
\hline 0.995 & 0.256 & -0.066 & -0.017 \\
\hline 0.999 & 0.273 & -0.066 & -0.018 \\
\hline 1.003 & 0.291 & -0.067 & -0.020 \\
\hline 1.007 & 0.308 & -0.068 & -0.021 \\
\hline 1.011 & 0.324 & -0.069 & -0.022 \\
\hline 1.685 & 0.841 & -0.564 & -0.475 \\
\hline 1.900 & 0.831 & -1.074 & -0.892 \\
\hline
\end{tabular}


The values for $d M R_{1} / d p_{1}$ are positive but less than 1. This means that given the parameters of $p_{2}=1, a_{1}=0.5, a_{2}=0.5, M=10, s=5$, marginal revenue is flatter than its demand curve for the price range shown above.

The value of $d M R_{1} / d p_{1}$ is independent of $\mathrm{M}$ but is sensitive to the value of $p_{2}, a_{1}$ and $\sigma$. For example, if $p_{2}>1, d M R_{l} / d p_{1}$ is negative for some price range of $p_{l} . d M R_{l} / d p_{1}$ can even turn negative when $a_{1}$ and $\sigma$ are increased. When $d M R_{l} / d p_{1}$ is negative, this means that $d M R_{l} / d q_{1}$ is positive (since $d p_{I} / d q_{1}$ is negative) and marginal revenue slopes upwards.

\section{Appendix 3: Components of Optimal Tariffs in the CES Model with Market Power}

The overall tariff set by a country in our model can be decomposed into 4 components as follows. Note that (i), (iii), and (iv) are positive tariffs but (ii) is a negative tariff (i.e., import subsidy). The presence of component (ii) in the model explains why we have relatively low optimal tariffs in our simulation results.

\section{(i) Gros-type tariff}

Given this model where firms set markup prices in all goods (non-numeraire) markets, a tariff is desired for the reasons as explained in Gros (1987): When price exceeds marginal cost in the home good market, consumers see the price as the cost of home good but the true cost to the country is actually measured by the marginal cost. A positive tariff is desired in order to increase the domestic price of imports so as to bring the price ratio between home and import goods closer to the true social cost ratio between the two goods.

(ii) Rent-extraction-type tariff (to extract rent from foreign firm with market power)

An import subsidy is desired as explained by Helpman and Krugman (1989). With a CES demand function in this model, the demand curve is steeper than its marginal revenue curve (see Appendix 2 for derivation of CES demand and its marginal revenue). This means that marginal revenue declines more slowly than price and it is therefore welfare-improving to have an import subsidy as the gain by the consumers due to fall in prices outweighs the cost of import subsidy which is determined by the slope of marginal revenue curve (Helpman and Krugman: Chapter 4, pp. 54-55 and Figure 4.4).

(iii) Marginal-import-cost-type tariff

This is the standard optimal tariff. It arises when the marginal cost rises when output rises explained by Helpman and Krugman (1989: Chapter 4, p. 52). 
(iv) Export-tax-equivalent-type tariff

When the firms engage in Bertrand competition, there is a case for export taxation. This is because the firms perceive a more elastic demand curve (and thus a more elastic marginal revenue curve) than the true demand and true marginal revenue. The incorrect perceived demand and marginal revenue results in an export price (an export amount) that is lower/higher than the economy's optimum. An export tax can be used to correct this wrongly perceived demand function (Helpman and Krugman, 1989: Chapter 5, pp. 97-102).

Given that export tax is not a policy tool in the model, the Lerner's symmetry theorem (Lerner, 1936) which states that a tariff can achieve the same effect of an export tax suggests that part of the tariff imposed in this model acts as an export tax. ${ }^{14}$

${ }^{14}$ When markets are in Cournot competition, firms set output quantity assuming others do not change theirs. A firm has also a perceived demand curve that is less elastic than the actual demand curve. This causes an underexport and therefore a rationale for a negative export tax; i.e., export subsidy. 